\title{
Communication Law - a soft axis of Communication discipline
}

\author{
Ştefan Vlăduţescu \\ University of Craiova, 13 A. I. Cuza Street, 200585, Craiova, Romania \\ E-mail address: stefan.vladutescu1@gmail.com
}

ABSTRACT

The study is circumscribed to Communication Science Funda tan to highlight the place of Communication Law in the communication syst nas an aca ic d scipline. For this is taken as reference system The Theory and Standard $g / 0$ munication xis previously developed by Ştefan Vlăduţescu (2013): communication uni rse is vanized, at the moment, compared to 15 fields of communication; these differ by the cal axis, $b$ vope and consistency of structure and the cords that generate the movement the internal dev opment in field. The Communication Law is the field of knowledge organiz around the law axis. This is a soft axis of Communication discipline.

Keywords: Traditions Standard-Matrix R. T Cra ves Stanuaru-Matrix; Communication Law

\section{INTRODUCTION}

Thomas Kuhn is ane w introduced in the ontology of the science the paradigm concept. He shows th concept $\zeta$ use "in two different senses": "on the one hand, it stands for the entir cons tion of beliefs, values, techniques, and so on shared by the members of the gren coms ity. On the other, it denotes one sort of element in that constellation the co crete puz Ae-solutions employed as models or examples, can replace explicit ruks bus for the solution of remaining puzzles of normal science" (Kuhn, 1998 $\mathrm{p}$ 175). We o ct fro $\mathrm{h}$ here the irradiating significant concepts: "paradigm" and "com nun ". "Co nity" is the scientific community, that the wide assembly of those de wi 1 science or a science: "a scientific community consists (...) of the practitioners of a scio cypen communities can even be structured as "schools in the science" (Kuhn, 1998, p. 77), So, the paradigm, as postulated T. Kuhn has two coordinates of scientific catagraph. at we see it as a whole in which the senses are melted and for which the theoretical scission does not mean inconsistency. Our interpretation makes from paradigm a synthesis of the features of a rigorous science and robust, that is strong and well anchored in the scientific environment. A rigorous and robust science/theory is a strong science/theory.

In paradigm we find the most of the major components of a "strong science". The paradigm is the constellation of certain shared options for maintaining or reforming of a science. In constellation we have to decipher the springs of revolutionary replacement of some of the "normal science". To revolutionize the science, it starts from the "normal science". The 
tracks of development start from its core, consisting of its defining components. The core of a science consists of which makes it to be what it is and not something else and what else gets without leaving the quality of what science itself is. We sustain that the first meaning distinguished by T. Kuhn ("beliefs, values, techniques") is the one that includes "epistemology" ("beliefs"), axiology ("values") and methodology ("techniques"). The second meaning highlighted ("models or examples") involves ontology ("models", "examples"). In other words, the paradigm results as a constellation of ontological, epistemological, methodological and axiological changes of the "normal science".

Besides of T. Kuhn's point of view there are also other relevant, some of them are applied to communication. For example, J. A. Anderson considers that a complete theory ve four components: ontology, epistemology, praxeology and axiology: The ontolo y of a the makes a claim about what is. (...) The epistemology of a theory makes a claim a th what know. (...) The praxeology of theory makes a claim about how it is do . ......) vlly, $t$ axiology is the study of value" (Anderson, 1996, p. 2). Also, Rober T. C ig tah out "epistemology, ontology, axiology and praxeology" (Craig, 2013,

\section{COMMUNICATION AXES STANDARD-MATRIX}

Finn Frandsen şi Winni Johansen (2014) take o a reference sys m R.T. Craig's thesis concerning "communication theory as a field" and th is of ,seven traditions of communication theory". In connection with these nuclear thes addressed several questions: a) "Is communication theory a field or a discipline? If yes, cohe nt is this field? Does it have to be coherent? Is it one field or several fie "b) regarung the seven traditions: "But what happened to public relations, organizationa con icotion, business communication and corporate communication?" (Frandsen \& Joh v n, 20,4, p. 24). Resulting in the alternative idea is that the questions are qu ing two sentences. This idea is convergent with the position expressed by our articl "A CC apletion the Traditions Matrix-Standard-R. T. Craig, Induced by the Transformat on con-as-a-Field Membrane in Communicationas-a-Universe Membrane' Americ. 'nternational Journal of Contemporary Research, 3(10), (2013). There we shoy through theses, Robert T. Craig gives profile to an ideational configuration that e ca Membrane of the Field; that centers on the idea that communication of field: ac ible, ordering, homogeneous, clear delimitated and robust configured. "Ne un "erstand "Nembrane" as an elastic, coherent, dynamic, and vibrant ideational co ru ation at modulates the trans-paradigmatic thinking of a scientific community. Me ane in acates, more than a paradigm shift, a substantial and radical change of th IIn thoug " an area of study)". However, we mention in the article that the image " $\$$ nuni ation as field " is a conceptual membrane that turned into "communication as an univo "ane, "communication as a multi-field". Also, we underline that "The commu, tion is multi-space structure and multi-universe" (Vlăduţescu, 2013).

App ance almost consolidated is that in communication domain there is not an ontology, an epistemology, a methodology, an axiology. The reality is that, in various stages of development, all of them exist. Hard work of researchers made to base some components or "branches" of the communication discipline. Raul Fuentes Navarro talks about four dimensions of communication: "gnoseological, teleological, praxeological (...) ethics" (Navarro, 1999, p. 64).

On the development of a communication disciplines, Robert L. Heath and Jennings Bryant highlight: "An academic discipline grows because of what its scholars share. To this 
end, scholars need to understand the discipline history, have a common sense of the object of inquiry, focus on similar and compatible questions, agree on the best methodologies, and create a common terminology, or lexicon, with which to discuss the discipline " (Heath \& Bryant, 2000, p. 89). As we see the issue of ontology ("common terminology or lexicon") is placed last, even it is decisive. There are evoked, epistemology ("object of inquiry", "questions"), methodology ("methodologies") and history ("discipline's history").

Stephen W. Littlejohn and Karen A. Foss think epistemology, ontology and axiology as "philosophical assumptions" that "every theory, explicitly or implicitly, includes" and refers to the "nature of knowledge and how it is obtained, what constitutes existence, and what is valuable" (Littlejohn \& Foss, 2008, p. 16). The two reputed experts enum ch epistemology, ontology and axiology and treat them in this arrangement. On t $t^{1}$ other ha they conceive the three elements as "the branch of philosophy." That is, the ve them foreign branches. We conceive them as internal axis. In addition, we talk n anly a t 3 ax , but 15 .

For a discipline to be imposed and to develop are required an st ne 1 - 1 - a efined ontology and a realistic epistemology, and besides them a metb oulog axic ogy, how retarded they are. The accreditation process is conditioned their sh of a broad community of scholars, researchers, theorists, scie ists. intology, epistemology, methodology and axiology are primordial. We can s? that thes are hard axes of communication: ontology-A1, epistemology-A2, me nodology-A3, a ology-A4. Soft Axes are 11, that is: history-A5, psychology-A6, sociolog. A7, anthropology-A8, hermeneutics-A9, praxeology-A10, ethics-A11, logics-A12, ecology-A philosop y-A14, and communication law-A15.

Communication has integrated in its autonomurs existence as social science 15 axes: communication ontology (ontology of Oon rytion), communication epistemology, communication methodology, communic to n xiology, communication history, communication psychology, co nication sociology, communication anthropology, communication hermeneutic co municat 1 praxeology, communication ethics, communication logics, com un ti communication philosophy, communication law. We can talk, within commun ion, about 15 fields of communication. Robert T. Craig retained the whole con ation as a field, and communication theory "as a dialogicaldialectical field" (Cr g, 1 $\quad$ p. 199)? We consider that communication is not only a field, is not only a space, is not only susti-faced object. We sustat communication is much more. Comm nicatio is multi-s pace and multi-structure universe. We see communication as a systemic a rs with 5 intersected fields by different consistency and various levels of cohesion Comm ication is an irregular and heterogeneous universe: multi-space and multistruc are. ch fiel ystallized around an axis and appears as an area with a certain systemic 10 on, a specific o sentation, with a certain internal coherence of the structure. In the center of tho aro field strength is the force axis. No axis is of the field, but the field is of the axis.

Our pinion is that the 15 components, branches should be considered axes of communication, trails, tracks of theoretical constructive-cognitive-cogitative crystallization and practical-applicable of communication. Axes are also, pillars and specialties of the discipline of communication.

Our reasoning is as follows. Philosophy until Gottfried Wilhelm Leibniz and Immanuel Kant was an integrative discipline of science, generally of knowledge, because the great philosophers were also great scientists. Once with the most important philosopher of the nineteenth century, Georg Wilhelm Friedrich Hegel, Philosophy is isolated of science and is 
installed as autonomous discourse which no longer incorporates science, but explains it. The integrative philosophy and explanatory philosophy were presented as coherent cogitative system: ontology, gnoseology, axiology, logic, ethics, aesthetics, etc.. Once arrived at Martin Heidegger and Ludwig Wittgenstein, philosophy enters the implosion. The system idea collapses completely. Philosophy is developed as interrogation, as reflection on the major themes of existential condition proximity and social of mundane human; focuses strongly on language issues. So it is that the system decays: some of its elements are self-sustaining, while others remain as "dead branches" of philosophy.

Our idea is that "dead branches" can be green. They must be revived. Be reformed and transformed into useful tools in theory and practice. From components of philosophy epistemology, methodology, axiology, praxeology etc., become components $a$ theories . sciences. It is a process of grafting. Dead branches are grafted, they are gratt $n$ the ali trunk and strong of the science. Meditation- philosophy lives his destiny orphilo hy, b $i$, alternatively, as a fractal, is also becoming an internal branch of science of scio tific c "ave system or of the cogitative theoretical system. Having lost branches, pb iosopl ica trunk forms with them a useful set of branches able to be restored to a cm lito ew sci aces, new cogitative systems absorb as own components the branches of "osophy ar orb generic as branch the reflective method of the philosophy. Since tak g ol the branc,es of a separate construct that tends to keep them, the new cogitative tom inte tes them axes. We conceive axis as internalized polarizing branch of spe ific knowledge.

On this preliminary argument we base the co nitive cogitative constructive approach. This is guided by ordering axes thesis: communicatic ets 15 inte nal constitutive axes around which crystallize communicational synchronic cogn and $d$ achronic, and do it systemic and procedural functional. Research led us conclusion that over time, communication was approached from 15 perspectives: nto 1 epistemological, methodological, axiological, historical, psychological, ologi al, anthropological, hermeneutic, praxeological, ethics, logic, ecolo philoso hical and legal. It was investigated on crystal structure of the 15 axes that ar actua interna cundamentals pillars of communication. The overall internal communicat on observed approaches are centered on the axis of internal communicatio 1. Comm cation was structured until today on 15 axes and made incidents 15 approach

The 15 axes rgan whole communication domain: it unify, give coherence as communicationg space (the ${ }^{-i}$ space), give it cohesion as structure (the multi-structure), give it the $\mathrm{p}$ ssibilit to integr ate further communicational emergency. All studies and all theories of cu nu acation can be distributed on one of axis or on inter-axial zone: we can speak of commu. ation s tology studies, ontological theories of communication, ontological standaras Comm ation, it may retain communication epistemology studies, theories of co unic tion epis,emology etc. Each communicational concept can receive an axial deten atological communicational concept, epistemological communicational concept, rmeneutic communicational concept, ethics communicational concept etc. Each ontologica nodel of communication will get a specific axial attribute: epistemological model, axiological model, hermeneutic model, ecological model etc. Contributors of the axes are defined as reference systems establishers. Communication ontology believe that all communication is ontology, communication epistemology considers that all communication is epistemology. Pan-communicators behave as if everything would be communication. How is natural, to focus on communication history axis, communication can be seen as the history of communication: "A discipline is the history of that discipline" (Dobrescu \& Bargaoanu, 2007, p. 20). The standard of communication axes envisages that are accredited at least 15 approaches 
that mutually support communication and which emphasize the polymorphic nature of the communication field.

Around each axis revolves strings. Taxonomic they can be opened: if they touch tangentially the axis or lie at least one end in the zone of topic irradiation of axis. Or they may be closed: if their vibration or their extension falls entirely on the magnetic zone of the axis. In the field of communication, the axes are clearly delineated. They does not intersect only in volcanic core that means "communication". For example, communication logics axis and communication philosophy meet only which means distributed mutual idea that is the core of communication. To consider like C. G. Christians, one of the reputed specialists in communication ethics, that communication ethics would be "a branch of applied ph: of moral value and rules" (Christians, 2008) means to subsume one axis to another $?$ is and car a specialty of the discipline. It is true that Ethics was a branch of philosophy. $\mathrm{b}$ vhilosop has lost the power to direct the ontology, epistemology, ethics, and th ther ts of $t$. Branches were removed from the trunk and live independently. Comm nicati $n$ ethio one, and the philosophy of communication is different. It is true that some o enstr of of the communication ethics axis or communication logics axis touch ar acm ve cons nant with the open strings of the communication philosophy axis or otb axes. In su ases we deal with inter-axial research, multi-axial, trans-axial. These $c$ nplo esearche are not multidisciplinary.

They record only analog in transdisciplinary t' eory of Basarab rcolescu (2008): the axes are not disciplines, but specialties of a certair discipline. In our case, the discipline is communication (no matter what we call, commu ation scier ce, communication theory, communicology, communication studies, communica studv or sciences de l'information et de la communication) (Zhaoxun, 2005; Zhao 2007). Mur alscipline is communication, axes are specialties of communication: commun atry cology, communication methodology, communication history etc. By establishing a stand rd of axes, by axiology, avoids what Andrew Abbott called "the chaos iplines that disorder in "disciplinary system" (Abbott, 2001, p. 122).

"Axi-alization" of co "mu to constitution of a multi-space of communication and giy s conere and cohesion to the global field of communication. Beyond a default unif ne con thication thinking on 15 axes will avoid the risk of disorganizing fragm tatio, ordering fragmentation.

Diagramm ato represent. nof the idea that lies behind the ordering axes thesis appears as a sphere in which hey meet,ach 15 vectors bidirectionally. Axes have one end which, as vectors, mea $\mathrm{cl}$ other in the core of extended spherical, permeable and flexible of communication. "iile at ne end vector comes to nuclear meeting, the other end extending in a dir ctio f non- ng the communication space. Communication appears thus as multisp Sin the structure has on each space created around and along each axis and a different cons $y$, an speak of a heterogeneous structure. The heterogeneous structures have intense turing nodes and nodes of structural relaxation. Consequently, the axes will reveal in the glob structure of communication regional structures with recognizable profile. After creating a multi-space of communication, our axial perspective enables also highlighting of multi- structure.

The Communication Laws Axis - A15 polarizes and unifies the research regarding social relations with respect to communication, regarding their completion and licensing. "The law, in general, shows Maria Năstase Georgescu (Georgescu, 2004), is a set of rules of conduct and principles sanctioned and guaranteed regulating social relations essential to society at a time to ensure social order and determination freedoms and rights in society". Among the experts in 
this area of communication, there are: A. Meiklejohn (1948), T. I. Emerson (1970), J. A. Barron (1973), C. Edwin Baker (1989), K. Middleton, R. Trager, B. F. Chamberlin (1999), L. Day (1999), D. T. Popa (1999), I. Muraru (1999), V. Dabu (2003), M. C. Eremia (2003), Laura Stein (2006), J. J. Hemmer (2006), C. Edwin Baker (2007), K. H. Youm (2009), M. NăstaseGeorgescu (2009), P. Siegel (2011), Cristina Anca Păiuşescu \& Oana Duţă (2011). M. Kent, W. E. Lee (2012).

\section{CONCLUSIONS}

We see the 15 approach axis not as external branches of other sciences or $t^{\prime}$ eories, bu internal coordinates of communication domain. Understanding that any theory th vill deliv someone will enroll voluntarily or involuntarily in irradiation of an axis wo can $\mathrm{k}$ free communication and to develop its study on what direction we want. Ir additi $\eta$, an cod framework allows any para-consistent views or contradictory to fit sid, not utorde of communication a mediator. Axes are organizers infusers and cog at e in iators. ney wrap convergent the spectrum of research so far. However, let op divergence for open minded.

This work was partially supported by the grant number $33 \mathrm{C} / 2$ the University of Craiova.

\section{References}

[1] J. A. Anderson (1996). Con unid tion Thesry: Epistemological Foundation. New York: Guilford Press. [2] Andrzej Borowsk rnational, érs of Social and Humanistic Sciences 14 (2014)
7-17.

[3] T. Kuhn (1998). The struct of scientific revolutions. ( $3^{\text {rd }}$ ed.). Chicago: Chicago Univers Press

[4] Sebastian K Janusz Jrabara, Michal Kolcun, International Letters of Social and

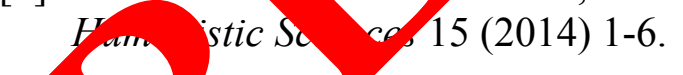

[5] H. Lum (2010). Journalism Law and Regulation. In K. Wahl-Jorgensen \& T. H Zscn, (wds.), The handbook of journalism studies (pp. 279-294). Routledge.

[6] L. L. I (2006). Speech rights in America: The First Amendment, democracy, and the media. University of Illinois Press.

[7] S. W. Littlejohn, K. A. Foss (2008). Theories of human communication. ( $9^{\text {th }} \mathrm{ed}$.). Belmont, CA, Thompson Wadsworth.

[8] M. Kent, W. E. Lee (2012). Law of Public Communication. ( $8^{\text {th }}$ ed.). Prentice Hall.

[9] A. Meiklejohn (1948). Free Speech and Its Relation to Self-Government. New York: Harper \& Row. 
[10] W. Johansen, F. Frandsen (2014). Communication Theory as a Field, but which Field? Revisiting Craig (1999). Welcome to Nordkomm.

[11] J. J. Hemmer (2006). Communication Law. University Press of America.

[12] Andrzej Borowski, International Letters of Social and Humanistic Sciences 14 (2014) $33-41$.

[13] D. T. Popa (1999). Dreptul Comunicării. București: Editura Norma.

[14] K. Middleton, R. Trager, B. F. Chamberlin (1999). The law of public communication. $\left(5^{\text {th }}\right.$ ed.). New York: Longman.

[15] A. Abbott (2001). Chaos of disciplines. Chicago: University of Chicago P ss.

[16] A. Traistaru, M. Avram, International Letters of Social and Humanis Scto 13 (2014) 79-88.

[17] Andrzej Borowski, International Letters of Social and Humanisi cie ces 4 (2013) 70-74.

[18] R. L. Heath, J. Bryant (2000). Human Communication ha and Rese h: Concepts, Contexts and Challenges. ( $2^{\text {nd }}$ ed.). London: Routledo [19] M. N. Georgescu (2004). Dreptul Comunicarii: specte Metodoly ce. Revista de Drept
Public.

[20] A. Borowski, International Letters of Social an Yumanisti Sciences 11 (2014) 1-168

[21] P. Siegel (2011). Communication Law America. Rowman \& Littlefield.

[22] M. C. Eremia (2003). Dreptul Comunic rii.r. Editura Credis.

[23] T. I. Emerson (1970). The Sy of Free om of Expression. New York: Random House.

[24] C. Edwin Baker (1989 And Freedom of Speech. New York: Oxford University Press.

[25] P. Dobrescu, A Bâr, onu (200), Intrebări incomode în debutul unei cercetări istorice. In P Dubresc. Bârgăoanu \& N. Corbu (Eds.), Istoria comunicării. Bucureşti com unicare.ro.

[26] Andrey ro ski, If ernational Letters of Social and Humanistic Sciences 2 (2014) 110-121.

[27) E. D eux (19, Droit de la communication. Paris: LDGJ.

[28] 13);

[29] V. Dąou (2003). Dreptul comunicării. Bucureşti: Editura SNSPA.

[30] R. T. Craig (1999). Communication theory as a field. Communication Theory 9(2) 119-161.

[31] C. G. Christians (2008). Ethics in Journalism. In W. Donsbach (Ed.), The International Encyclopedia of Communication. Oxford, UK, and Malden, MA: Blackwell Publishing.

[32] R. T. Craig (2013). Constructing theories in communication research. In P. Cobley \& P. J. Schulz (Eds.), Theories and Models of Communication, pp. 39-57. Walter de Gruyter. 
[33] B. Ślusarczyk, A. Broniszewska, Entrepreneurship of Women in Poland and the EuQuantitative Analysis. Polish Journal of Management Studies.

[34] S. Chirimbu, A. Dejica-Carțiș, E. Savu (2014). What skills do foreign languages teachers need in the $21^{\text {st }}$ century? An intercultural configuration. Professional Communication and Translation Studies.

[35] J. Tabor, Place of Non-formal Education in the Career Building Process. Polish Journal of Management Studies.

[36] I. Muraru (1999). Protecţia Constituţională a Libertăţilor de Opinie. Bucureşti: Lumina Lex.

[37] Janusz Grabara, Michal Kolcun, Sebastian Kot, International Journal of ration an Research 2(2) (2014).

[38] Andrezj Borowski, International Letters of Social and Humanisti Scien 69-74.

[39] M. Năstase-Georgescu (2009). Dreptul Comunicării. Edit a Univers

[40] Aurelia Traistaru (2013). Consolidation of the green $n$ rken vrofile iv current austerity period. Jokull.

[41] J. A. Barron (1973). Freedom of the Press for V hom: The Right of Access to Mass Media. Bloomington: Indiana University Press

[42] J. H. Gasderell, International Letters of Social a Human stic Sciences 22 (2014) $85-91$.

[43] A. Herbuś, B. Ślusarczyk, Polish Journ of cment Studies 6 (2012) 234-240.

[44] Vlad Roșca, Management \& Keting 9) (2014).

[45] R. F. Navarro (1999). Lo vestig ción de / comunicación en América Latina: condiciones y perspec as Xiálogos de la Comunicación.

[46] Cristina Anca Păiu scu, Oana ță (2011). Dreptul comunicării. Consideraţii teoretice şi legislaţia rele am Bucureştı. ditura Universitară.

[47] Răzvan Bar' escu, Ro, ian Economic Business Review 7(2) (2012) 77-86.

[48] Vlad Ro ca $(20$ 2). The P Mitical Economy of World Heavyweight Boxing during the Greats ion. T zoretical and Applied Economics.

[49] D Dragh (20\%). Illegal and Harmful Content on the Internet: Or Substantial Offe, es and Isdiction: Comparative Analysis (Doctoral dissertation, University of

[50] B. olescu (Ed.). (2008), Transdisciplinarity: theory and practice. Hampton Press.

[51] Song/Lhaoxun, Journal of International Communication 3 (2007) 010.

[52] V. Boureanu (2013). Tradiţie şi modernitate în comunicarea internă din bibliotecile universitare româneşti. Annales Universitatis Apulensis. Series Philologica. 
[53] S. Zhaoxun (2005). Contemporary Chinese organizational culture in hero storytelling: A rhetorical analysis. Excess \& Organization.

[54] Ion Stavre (2011). Comunicare audiovizală: aspecte ale europenizării societăţii româneşti. Tritonic.

[55] Jason L. Powell, International Letters of Social and Humanistic Sciences 7 (2014) 22-30.

[56] O. Băluţă, A. Dragolea, A. Iancu (2007). Gen şi interese politice. Teorii şi practici, (Gender and political interests. Theories and practices). Polirom, Iaşi.

[57] Jason L. Powell, International Letters of Social and Humanistic Sciences 177-183.

[58] Jason L. Powell, International Letters of Social and Humanistic Sci nces 17( 1-60.

[59] Donovan A. McFarlane, International Letters of Social and $y$. Sciend 4 (2013) 35-44.

[60] Paul Bukuluki, International Letters of Social and Hu anis Tciences (2013) 27-44.

[61] Kinga Dziwańska, International Letters of Social ana Yumanisi. zences 7 (2013) 96-112.

[62] Tomáš Hes, Anna Poledňáková, International ters of Sod al and Humanistic Sciences 2 (2013) 18-31.

[63] Andrzej Borowski, International Lette 46-53.

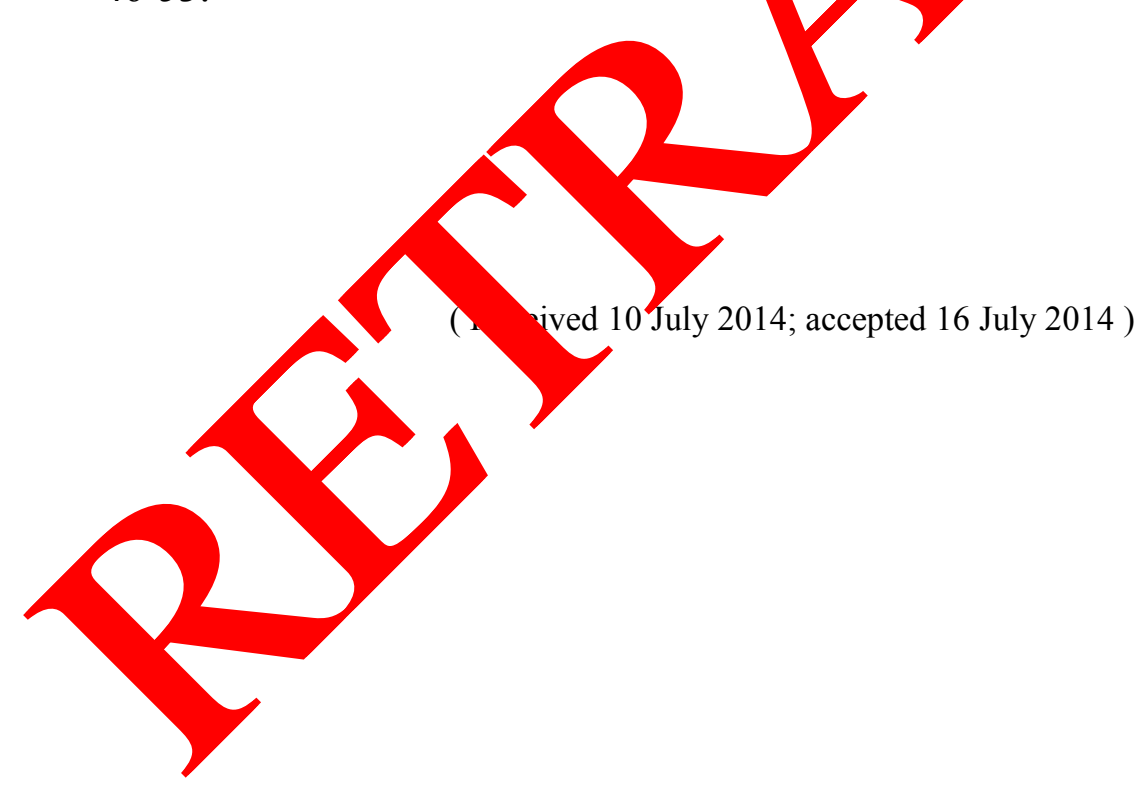

